\title{
PENERAPAN MODEL PEMBELAJARAN INKUIRI TERBIMBING UNTUK MENINGKATKAN HASIL BELAJAR SISWA KELAS VII PADA MATERI PENCEMARAN AIR DAN TANAH DI SMP BABUS SALAM SILO
}

\author{
${ }^{1}$ Wildani Hafifah, ${ }^{2}$ Diah Sudiarti, ${ }^{3}$ Umi Nurjanah \\ ${ }_{123}$ Pendidikan Biologi, Universitas Islam Jember \\ ${ }^{1}$ wildanihafifah01@gmail.com, ${ }^{2}$ diah.sudiarti23@gmail.com, ${ }^{3}$ kholidumi@gmail.com
}

\begin{abstract}
ABSTRAK
Penerapan model pembelajaran inkuiri terbimbing untuk meningkatkan hasil belajar siswa kelas VII pada materi pencemaran air dan tanah di SMP Babus Salam Silo, bertujuan untuk meningkatkan hasil belajar siswa kelas VII di SMP Babus Salam Silo dalam mempelajari pencemaran air dan pencemaran tanah dengan menggunakan model pembelajaran inkuiri terbimbing. Jenis penelitian yang digunakan adalah Penelitian Tindakan Kelas (PTK), yang terdiri dari 2 siklus. Metode pengumpulan data dengan tes. Berdasarkan hasil penelitian, persentase hasil belajar siswa pada pra siklus sebesar $56,5 \%$, siklus I sebesar $70,1 \%$ dan siklus II sebesar $76,2 \%$. Hal tersebut membuktikan bahwa hasil belajar siswa dapat meningkat dengan diterapkannya model pembelajaran inkuiri terbimbing. Model pembelajaran inkuiri terbimbing dapat mengatasi rasa jenuh dalam kegiatan pembelajaran.
\end{abstract}

Kata kunci: Peningkatan hasil belajar, model pembelajaran inkuri terbimbing.

\section{ABSTRACT}

The implementation of guided inquiri learning models to improve learning outcomes of Grade VII students on water and soil pollution material in junior high school babus salam silo, aiming to improve student learning outcomes in Grade VII in junior high school greetings Babus Salam Silo. Middle School in studying water pollution and soil pollution by using a guided inquiry learning model. This type of research is Classroom Action Research (CAR), which consist of 2 cycle, the method of collecting data with tests. The percentage of student learning outcomes in pre-cycle of $56.5 \%$, the first cycle of $70.1 \%$ and the second cycle of $76.2 \%$. This proves that student learning outcomes can improve with the application of guided inquiry learning models. The guided inquiry learning model can overcome boredom in learning activities.

Key words: Improved learning outcomes, guided inquri learning model

\section{PENDAHULUAN}

Hasil belajar bukan hanya berupa penguasaan pengetahuan, tetapi juga kecakapan dan keterampilan dalam melihat, menganalisis, memecahkan masalah, membuat rencana dan mengadakan pembagian kerja. Dengan demikian aktivitas dan produk yang dihasilkan dari aktivitas belajar ini mendapatkan penilaian (Joyoatmojo,2006).
Hasil belajar adalah sebagai terjadinya perubahan tingkah laku pada diri seseorang yang dapat di amati dan diukur dalam bentuk pengetahuan, sikap dan keterampilan. Perubahan tersebut dapat diartikan sebagai terjadinya peningkatan dan pengembangan yang lebih baik dari sebelumnya yang tidak tahu menjadi tahu. (Hamalik, 2009).

Berdasarkan hasil wawancara dan observasi dengan guru mata pelajaran 
biologi yaitu ibu Yenny Dwi Arini S.Pd di SMP Babus Salam Silo yang telah menjelaskan bahwasanya terdapat beberapa siswa khususnya mata pelajaran IPA nilainya rendah atau masih di bawah KKM, sedangkan berdasarkan hasil observasi yang telah dilakukan oleh peneliti yaitu sebagian siswa juga masih ada yang bicara sendiri ketika guru sedang menyampaikan materi, sehingga bisa dikatakan konsentrasi siswa masih kurang, selain itu juga tidak tersedianya sarana dan prasarana yang mendukung contohnya seperti alat peraga dan yang lainnya. Salah satu cara untuk mengatasi masalah tersebut adalah diperlukannya suatu model pembelajaran yang diharapkan dapat meningkatkan hasil belajar siswa, dan salah satunya adalah model pembelajaran inkuiri terbimbing. Model pembelajaran inkuiri terbimbing ini dipilih karena karakter siswa kelas VII SMP Babus Salam Silo masih membutuhkan bimbingan guru.

Pembelajaran berbasis inkuiri terbimbing merupakan suatu teknik atau cara yang digunakan guru dalam proses pembelajaran, dimana siswa tersebut aktif mencari serta meneliti sendiri pemecahan masalah itu dan mampu mengemukakan pendapatnya, merumuskan masalah, merencanakan eksperimen, melakukan eksperimen, menganalisa, serta menarik kesimpulan (Roestiyah, 2012). Menurut (Depdiknas 2003) secara umum menyebutkan enam langkah pembelajaran inkuiri, yaitu sebagai berikut : Orientasi, Merumuskan masalah, Merumuskan hipotesis, Mengumpulkan data, Menguji hipotesis, dan Merumuskan kesimpulan

\section{METODE PENELITIAN}

\section{Rancangan Penelitian}

Penelitian ini bertujuan untuk mengetahui peningkatan hasil belajar siswa kelas VII di SMP Babus Salam Silo dengan menggunakan model pembelajran inkuiri terbimbing maka jenis penelitian yang digunakan adalah Penelitian Tindakan Kelas (PTK).

\section{Indikator Keberhasilan dan Siklus}

Indikator keberhasilan dalam penelitian tindakan kelas ini adalah jika di kelas tersebut telah terdapat minimal 70\% siswa, telah mencapai skor KKM $\leq 70$ dengan diaplikasikannya model pembelajaran inkuiri terbimbing dengan mengumpulkan data hasil belajar siswa dari siklus I sampai siklus II.

\section{Prosedur Penelitian}

Penelitian ini dirancang menjadi 2 siklus, pada tahapan tiap siklusnya meliputi: perencanaan, tindakan, pengamatan dan refleksi.

\section{Metode Pengumpulan Data}

Dalam penelitian ini peneliti menggunakan metode tes, yang dimaksud yaitu tes hasil dari siklus I dan siklus II, yang mana siswa diberi soal uraian sebanyak 10 butir pada siklus I dan 10 butir pada siklus II.

\section{Analisis Data}

Dalam penelitian ini analisis data yang digunakan adalah analisis deskriptif kuantitatif terhadap data yang diperoleh dari hasil belajar siswa.

Untuk menghitung hasil belajar siswa digunakan rumus: 


$$
\mathbf{P}=\frac{\sum N 1}{\sum N} \times 100 \%
$$

Keterangan

$\mathrm{P}$ :Presentase ketuntasan hasil belajar siswa

$\sum N 1$ : Jumlah siswa yang tuntas

$\sum N$ : Jumlah total siswa

(Slameto dan Safida 2010).

\section{HASIL DAN PEMBAHASAN}

Penelitian Tindakan Kelas (PTK) ini bertujuan untuk meningkatkan hasil belajar siswa melalui model pembelajaran inkuiri terbimbing. Peneliti menggunakan model pembelajaran inkuiri terbimbing agar hasil belajar siswa meningkat atau sesuai KKM. Data hasil belajar ini diperoleh peneliti dari hasil ulangan harian siswa setelah proses pembelajaran pada setiap akhir siklus selesai. Penerapan model pembelajaran inkuiri terbimbing dilakukan pada kelas VII SMP Babus Salam Silo yang dilakukan selama dua siklus yaitu siklus I dan siklus II.

Data hasil belajar yang diperoleh peneliti dari hasil belajar siswa melalui pembelajaran menggunakan model pembelajaran inkuiri terbimbing pada siklus I dan siklus II, yaitu dapat dilihat pada Gambar 1.

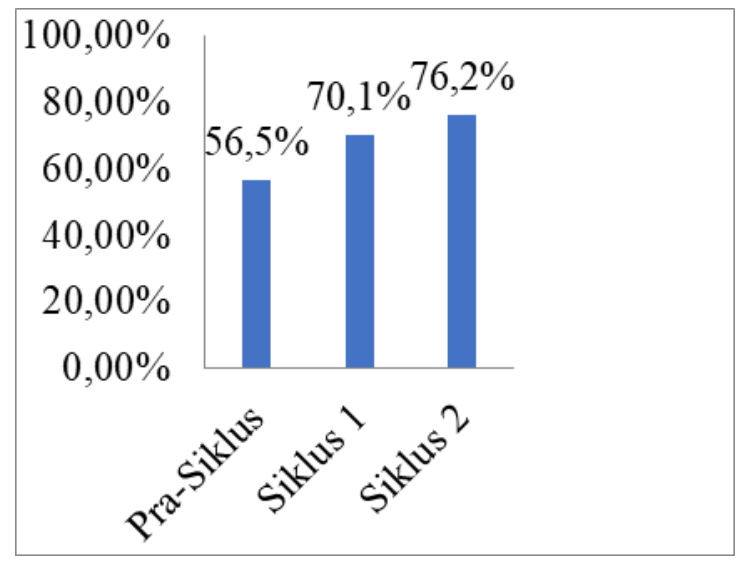

Gambar 1. Hasil Belajar Siswa
Berdasarkan Gambar 1, dapat dikatakan bahwa telah ada peningkatan hasil belajar siswa yakni dengan diperolehnya nilai persentase hasil belajar siswa pada pra siklus yaitu 56,5\%, siklus I mencapai 70,1\% dan diperolehnya nilai persentase seluruh siswa pada siklus II mencapai 76,2\%. Peningkatan persentase hasil tes yang terjadi antara pra siklus ke siklus I sebesar $13,6 \%$ sedangkan peningkatan persentase hasil tes yang terjadi antara pra siklus ke siklus II sebesar 19,7\% . Peningkatan persentase hasil tes yang terjadi pada siklus I ke siklus II yaitu sebesar 6,1\%, setelah diperoleh data-data dari pra siklus, siklus I dan siklus II, maka dapat diketahui bahwa hasil belajar siswa terjadi peningkatan atau dengan kata lain penerapan model pembelajaran inkuiri terbimbing dapat meningkatkan hasil belajar siswa

\section{KESIMPULAN}

Berdasarkan rumusan masalah, dapat disimpulkan bahwa penerapan model pembelajaran inkuiri terbimbing dapat meningkatkan hasil belajar siswa kelas VII pada materi pencemaran air dan tanah di SMP Babus Salam Silo. Hal ini ditunjukkan dengan adanya peningkatan persentase rata-rata hasil belajar siswa yang dicapai setiap akhir siklus. Pada siklus I diperoleh angka ketuntasan klasikal sebesar 70,1\%, berbeda dengan siklus II diperoleh angka ketuntasan klasikal sebesar 76,2\%. 


\section{DAFTAR PUSTAKA}

Departemen Pendidikan Nasional. 2003.

Pendekatan Kontekstual. Jakarta:

Departemen Pendidikan Nasional.

Hamalik, Oemar. 2009. Psikologi Belajar Dan

Mengajar cetakan Ke-6. Bandung: Sinar Baru Algensindo.

Joyoatmoyo, S. 2006. Belajar Mandiri: Bekal Untuk Menapak Jalan Menuju Belajar Sepanjang Hayat. Makalah disajikan pada kuliah perdana bagi mahasiswa baru jurusan Pendidikan Matematika Dan Ilmi Pengetahuan Alam, hlm.1-20. Surakarta: FKIP Universitas Sebelas Maret.

Roestiyah, N.K. 2012. Srategi Belajar Mengajar. Jakarta: PT. Rineka Cipta.

Slameto, 2010. Belajar dan Faktor yang mempengaruhinya. Jakarta: Rineka Cipta. 